\title{
Digging Deeper to Improve the Light
}

\section{Commentary on Witherington et al.}

\section{Ken Richardson}

The Open University, Berwick upon Tweed, UK

\author{
Keywords \\ Nonreproducibility levels · Presuppositions · Dynamics · Ideology · Individualism
}

We are living in a period when truth, and its systematic confirmation through science, has become increasingly slippery. A yawning gulf has been opening up between hype and reality created by what we might call the data fetishism. The speed with which "findings" are rushed into text - even in esteemed journals - with eyecatching press statements, then garbled as media soundbites swallowed by the general public and politicians, is beginning to turn science into something akin to show business. So, a crisis of confidence has emerged in the empirical sciences, several studies pointing to questionable research practices such as selective publication, cherrypicking (e.g., reporting only those variables, conditions, or analyses that yield the desired result) and, of course, opening up the nonreplication debates. In terms of wasted resources (wages and materials, but not including wasted time), the financial cost of nonreproducibility, "is estimated to be 28 billion dollars in the United States alone" [Jaafar and Maweni, 2016].

Psychology has had its fair share of these problems [Pashler \& Wagenmakers, 2012], but is further confused by the proliferation of debates around theories the legitimacy of which has been very difficult to pin down. The paper by Witherington et al. [this issue] is a worthy attempt to explain these tendencies in the field of human development, and to help turn the tide. Their solution is what they call conceptual analysis, which involves "two distinct levels of conceptual inquiry: the theoretical and the metatheoretical." The former - the concepts that make up theory - are what guide everyday inquiry, with the tendencies just mentioned. The metatheoretical level consists of the underlying concepts, philosophical beliefs and assumptions from which those theories, and the empirical lines they encourage, sprout. These are not themselves objectively substantiated, but, as these authors say, this level of analysis is sadly ignored, although much can be resolved by analyzing it.

\section{KARGER \\ E-Mail karger@karger.com www.karger.com/hde}

(c) 2018 S. Karger AG, Basel
Ken Richardson

26 Castle Terrace

Berwick upon Tweed, TD15 1NZ (UK)

E-Mail k.richardson@mac.com 
It is timely and important to be reminded of the need for such analysis. Whereas progressive leaps in the other sciences have sprung from such conceptual revolutions, the hit-and-miss search for consensus among psychologists in general, and developmentalists in particular, has been going on for too long. It was Lakatos, in the famous 1971 London conference, who accused psychology of "ad hoc theorizing," and Popper, in the same place, who poured scorn on psychology describing it as spurious, full of fashions and unbridled dogma. But their main remedy was for more methodological purism.

The philosopher R.G. Collingwood [1943], in his Essay on Metaphysics, may have been closer to the point. As he argued, every scientific statement is the answer to a question; but every question is based on a presupposition. So, all theories are based on presuppositions, and it is the duty of philosophers to expose and challenge them. The lesson of the train of criticism stimulated by Kuhn [1962] and others is that no scientific observations or facts are conceptually neutral: they are already saturated with theory before the observation begins. That seems to have been particularly the case for psychology. So, it is the cryptic assumptions shaping science, and its data gathering, that we need to examine if we want theoretical progress.

Witherington et al. [this issue] argue that this should be the duty of all of us. Theoretical concepts, they say, organize empirical observations and their interpretations. But the theories are shaped by, and rest upon, a level of pre-empirical and pretheoretical conceptual grounding, including philosophical beliefs and assumptions about the nature of reality. Major debates persist, they say, because disagreements really stem from this deeper level. Like Collingwood, they spot the need for "revealing implicit assumptions" of theories, and exposing the ideas that form the roots of the very questions being asked.

However, they do more than merely implore and advocate. The paper instructively illustrates how developmental science can do this by discussing the nature of one pair of contrasting presuppositions at the metatheoretical level, and then go on to illustrate how it has given rise to multiple, but contrasting, theories and their empirical sequelae.

Their exemplary metatheoretical divide is that between the Cartesian Split Mechanicism (CSM), on the one hand, and the Process-Relational paradigm (PR), on the other. They paint an excellent picture of the former as elemental, mechanical, and reductionist. But I would particularly like students to read the description of the PR as among the most concise and erudite I have come across (albeit with some minor reservations mentioned below). The contrast between the two sets of preconceptions is quite stark. I will consider how these have translated into metamodels in psychology and developmental theories in turn, before returning to the preconceptions below.

The first instantiation is epigenetics. Famously introduced by C.H. Waddington in the 1940s, the more recent tendency has been for the term to become a buzz word for a more acceptable form of traditional genetic determinism. Again, in recommended reading for students and other scholars, Witherington et al. provide an in-depth, circumspect description of the history and current usage of the whole concept.

This is important, because forms of determinism and reductionism seeped through twentieth-century genetics into more recent times in reasonable-sounding formats. Even the self-styled communist J.B.S. Haldane [1963], who favored cloning of "persons of attested ability" as a way to "raise the possibility of human achievement 
dramatically," also opined that "much that is classified as psychology would in my opinion better be classified as physiology of the sense, muscular coordination, and the brain."

We see this more recently in genome-wide searches for the alleged DNA roots of all form and variation, using terms like "epigenetics" and "environment" loosely, but only as factors that attenuate what is "in" the genes: i.e., more of a public relations exercise than genuine understanding. In contrast, Witherington et al. describe how Graham Gottlieb turned predetermined epigenetics into probabilistic epigenetics, so that "there are bidirectional influences within and between levels of analysis... gene, cell, organ, organism, physical, social or cultural environment."

The difference stems, they say, from the PR research paradigm, "with its emphasis on process, activity, change, emergence, and self-organization" (although they use the more ambiguous words "consistent with," as if there may or may not be an ontological connection). And they show how the view is a powerful antidote to the (still prevalent) idea that genes, phenotypes, and environments are causally independent and separable elements. Instead, PR returns development to center stage, as itself a constructive process, not merely a gene-directed assembly line of gene-determined parts.

The view is also consistent with the recent molecular biology that finds the genes as purely passive servants to the real self-organized dynamics of interlevel relations [Noble, 2016], themselves prone to having their sequences rewritten by top-down processes [Shapiro, 2013]. Accordingly, the paper is excellent on distinct meanings of "interaction," putting the term "innate" into proper perspective. It shows convincingly how, indeed, the problems underlying so many debates in psychology and human development are conceptual ones that data alone cannot resolve. It also shows why developmental psychologists, more attuned to the natural history, and cryptic roots, of phenomena, including their transformations over time, have so often been at the forefront of scientific progress in psychology.

New, and deeper ideas are often difficult to convey, but, on the whole, this is done with great skill and sense of audience. It is in the second topic - embodiment - where the distinction between theory and metatheory becomes less clear. The idea of embodied cognition arose as an escape from the computations-in-a-box model adopted in the cognitive revolution of the 1960s. But here the authors seem to be most concerned with the metatheoretical distinction between embodied and broader "enactive cognition" (i.e., whether the body is merely an influence on, or constitutional of, cognition). Specifically, they argue that embodied cognition theories assume the Cartesian mind-body dualism. Enactivist accounts, on the other hand, require the conceptual shift from that assumption as found in the PR. Debate between proponents, again, cannot be resolved at the empirical level, because differences lie at the metatheoretical level of cryptic assumptions. It is resolved "by emphasizing the co-determination of individual and environment," as in the PR model.

Students will hopefully learn from that. It may not be entirely clearly described - i.e., as a trinity of bridges between the body/biological, the personal/psychological, and the contextual/sociocultural. But it is not difficult to see how the conceptual shift involved in the PR approach better integrates levels of evolution and development. That is, we have to reject CSM-based embodiment theories, and accept PR ones, to understand how the body brings the world into the mind, and, thereby, its evolution, development, and history. 
I have other questions about depth of analysis to which I return below. But a brief word on levels of organization in living things may be in order, because it reinforces the PR message, i.e., that the relations between levels are more than what we usually think of as "bidirectional influences." The nonlinearity of multiple variables in constant nonequlibrium states creates dynamic attractor states at every level of organization, from the biochemical networks of the cell "up." Many investigators have observed how more complex, adaptable, structures readily emerge from interactions among attractors, through evolving hierarchical levels [Braun and Mattia, 2010]. Such coupled or nested attractor systems are highly creative in dealing with changing environments. Developmentally, this property of the dynamics of living systems may account for Piaget's [1988] concept of "reflective abstraction," for example. It suggests even greater contrast with the mechanistic preconceptions of the CSM.

The third topic concerns the metatheoretical preconceptions that guide choice of variables and data collection in research. Again, it depends on a set of pre-empirical assumptions that guide notions of "normality," thereby shaping expectations and theoretical models. The CSM encapsulates human existence as the normal, natural model of objective functions, detached from historical change and current contexts, and in that way it distorts human nature, often pathologically. It contrasts with alternative, if marginalized, theories, based on alternative preconceptions, which recognize natural bonds with nature, its diversity of species and other people, including those from previous epochs. Observations of hunter-gatherer tribes, for example, may suggest more accurate metatheoretical foundations for the study of human development. "In the realm of modern scientific inquiry, this relational alternative is clearly instantiated in the Process-Relational research paradigm" [Witherington et al., this issue]. That is, the PR perspective indicates how distorted our descriptions and theories of "normal" human development have been.

The paper concludes by emphasizing again the importance of conceptual analysis for resolving intense debates and conceptual confusions. In doing so, this may well be one of those landmark papers that cause us to pause, reflect and realign our scholarly activities. The examples are very good at revealing the need and making the point. In my remaining remarks, I simply want to add a few musings that might help it along.

One of the problems with conceptual analysis is that it inevitably throws up concepts that may be unfamiliar or vague to the readers we most need to convince. Consequently, some students and scholars might baulk at the unfamiliarity of some of the phraseology. As one description of the PR, for example, we find "dynamic action patterns... logically prior to" and defining "both conditions and resources". Or readers will encounter: "A key ontological feature of a holistic system is that it is endogenously active. There is no external force driving the system; rather, it is by its organic nature self-active. It is this activity of the system along with the system's organization that identify the system as one that is constantly changing in a dialectical manner."

Such passages will be understood by the initiated. But for the naïve, they might seem slightly mystical. They suggest, for example, that the system exists before it meets the conditions on which it acts and the resources it uses. How then did it come into existence? And if it changes, what changes it? Some help on the latter question - and more fundamental grounding - may be obtained from the work of Baverstock and Rönkkö [2014], Friston, Levin, Sengupta, and Pezzulo [2015], and others, who relate dynamic systems to basic laws of thermodynamics (although admittedly adding to the communication problem just complained about). This absence of further 
grounding may explain the plethora of formulations in the area. The student may ask, if these are based on common presuppositions, what divides them, and why?

That leads me to ask, how deep do the assumptions described for CSM really go? Do they equate, for instance, with Collingwood's "absolute presuppositions"? Is it enough to describe the CSM as itself a metatheoretical conception? After all, the CSM did not arise out of thin air and may itself be a theoretical formulation drawn from deeper metatheoretical foundations. Descartes (1596-1650) was writing at a time of politico-economic ferment and painful transitions to new forms of social order and control. As Negri [2006; c.f. Tally, 2008] noted, the emergent bourgeoisie of the seventeenth century confronted the power of monarchies and aristocracies to forge a new spirit of capitalism and radically restructure society. Descartes produced a "reasonable ideology" consistent with "the productive, social and cultural hegemony of the bourgeois class," thereby revealing "the profound interconnectedness between metaphysics and politics" [Tally, 2008].

As others have pointed out, the emerging competitive individualism - as a major presupposition of the new order - gave the new philosophers of mind a problem. This was how to put soul and body back together in a special way, "a way as to stand in need of nothing beyond themselves individually" [Whitehead, 1928]. Thus, Descartes bequeathed us the encapsulated mind, with its innate ideas, separated from a mechanical body. As Bertrand Russell [1962] explained, in Descartes, "everyone is thrown back on [her/his] personal existence as a basis for knowledge."

The new concept of the individual has since pervaded psychology; at first through the mediation of Hobbes, Locke, Hume and others; then through Spencer, Darwin and Galton, to every major branch of the would-be science. It is found most prominently today in so-called "evolutionary psychology," with its "Machiavellian hypothesis": the concept of the detached individual learning, thinking and behaving in the interests of the self, using social links purely as a means to personal ends.

Perhaps that is the major metatheoretical confusion hanging over us today, and most of modern psychology still struggles with it. No wonder there have been longstanding problems! It is to the credit of the PR perspective that it is taking the lead in freeing us from such ties. But the socio-economic roots at least explain why doing so is so difficult and may take some time yet. In explaining why the Copernican revolution took over 300 years, Kuhn [1957] said, "If Copernicus' proposal had had no consequences outside astronomy, it would have been neither so long delayed nor so strenuously resisted." Witherington et al. also deserve enormous credit for helping us see the root of the matter in developmental science, and what to do about it.

\section{References}

Baverstock, K., \& Rönkkö, M. (2014). The evolutionary origin of form and function. Journal of Physiology, 592, 2261-2265.

Braun, J., \& Matita, M. (2010). Attractors and noise: twin drivers of decisions and multistability. Neuroimage, 52, 740-751.

Collingwood, R.G. (1943). An essay on metaphysics. Oxford, UK: Clarendon Press.

Friston, K., Levin, M., Sengupta, B., \& Pezzulo G. (2015). Knowing one's place: A free energy approach to pattern regulation. Journal of the Royal Society Interface, 12, 20141383.

Haldane, J.B.S. (1963). Biological possibilities for the human species in the next ten thousand years. In G. Wolstenholme(Ed.), Man and hisfuture. Re-published in 2008 by Wiley. doi:10.1002/9780470715291. $\operatorname{ch} 22$. 
Jaafar, H., \& Maweni, R.M. (2016). A failure to reproduce: How bad biomedical science is holding us back. F1000Research, 5, 415.

Kuhn, T.S. (1957). The Copernican Revolution: Planetary astronomy in the development of Western thought. Cambridge, MA: Harvard University Press.

Kuhn, T.S. (1962). The structure of scientific revolutions, ed 2. Chicago, IL: University of Chicago Press.

Lakatos, I. \& Musgrave, A. (Eds.) (1971). Criticism and the growth of knowledge. Cambridge, UK: Cambridge University Press.

Negri, A. (2006). The political Descartes: Reason, ideology, and the Bourgeois Project. Translated by Matteo Mandarini and Alberto Toscano. London, UK: Verso (original Italian text 1970).

Noble, D. (2016). Dance to the tune of life. Oxford, UK: Oxford University Press.

Pashler, H., \& Wagenmakers, E.-J. (2012). Editors' introduction to the special section on replicability in psychological science: A crisis of confidence? Perspectives on Psychological Science, 7, 528-530.

Piaget, J. (1988). Piaget's theory. In K. Richardson \& S. Sheldon (Eds.), Cognitive development to adolescence. Hove, UK: Erlbaum.

Tally R.T. (2008) Reason and revolution redux: Antonio Negri's Political Descartes. Theory \& Event, $11,2$.

Russell, B. (1962). Wisdom of the west. London, UK: Macdonald.

Shapiro, J.A. (2013). How life changes itself: The Read - Write (RW) genome. Physics of Life Reviews, 10, 287-323.

Whitehead, A.N. (1928). Science and the modern world. Cambridge, UK: Cambridge University Press. 